\title{
Morphologic and morphometric characteristics of ascaroid worm, Ophidascaris piscatori in Xenochrophis piscator snake in Sidoarjo, Indonesia
}

\author{
Lucia Tri Suwanti ${ }^{1}$, Inggarsetya Syah Audini², Setiawan Koesdarto ${ }^{1}$ and Emmanuel Djoko Poetranto ${ }^{3}$
}

1. Department of Veterinary Parasitology, Faculty of Veterinary Medicine, Universitas Airlangga, Jl. Mulyorejo, Kampus C Unair, Surabaya, 60115, Indonesia; 2. Master Program Student, Faculty of Veterinary Medicine, Universitas Airlangga, Jl. Mulyorejo, Kampus C Unair, Surabaya, 60115, Indonesia; 3. Department of Veterinary Clinic, Faculty of Veterinary Medicine, Universitas Airlangga, Jl. Mulyorejo, Kampus C Unair, Surabaya, 60115, Indonesia.

Corresponding author: Lucia Tri Suwanti, e-mail: tswant@gmail.com

Co-authors: ISA: setyainggar@gmail.com, SK: setiawankoesdarto@gmail.com, EDP: poetranto2011@gmail.com Received: 02-04-2018, Accepted: 09-07-2018, Published online: 25-08-2018

doi: 10.14202/vetworld.2018.1159-1163 How to cite this article: Suwanti LT, Audini IS, Koesdarto S,Poetranto ED (2018) Morphologic and morphometric characteristics of ascaroid worm, Ophidascaris piscatori in Xenochrophis piscator snake in Sidoarjo, Indonesia, Veterinary World, 11(8): 1159-1163.

\begin{abstract}
Aim: The study was conducted to describe the morphology and morphometry of nematode worm in the stomach of Xenochrophis piscator snake macroscopically and microscopically using light and scanning electron microscopy (SEM).

Materials and Methods: The sample was 40 nematode worms that have been collected from 60 snakes which slaughtered at snake slaughterhouses in Sidoarjo, Indonesia. The worms (10 male and 10 female) were stained with carmine, and the others were sent to Indonesian Science Institute for ultrastructure observation by SEM. Some of the female worms were immersed in physiological $\mathrm{NaCl}$ and incubated to collect theworm eggs.

Results: Nematode worm in this study had three lips with almost the same size and it had papillae, so it was included in ascaridoid. The mouth of ascaridoids has three lips, the dorsal bearing two large outer papillae and the each lateroventral with one papilla. The body length and width of the male worm were $70-105 \mathrm{~mm}$ and $0.92-1.32$, respectively, with head diameter of $0.22-0.28 \mathrm{~mm}$. Dorsal and ventrolateral lips almost have the same size that was $0.10-0.12 \times 0.11-0.13 \mathrm{~mm}$. The length of interlabia was 0.06-0.08 mm, esophagus was 3.21-4 mm, tail was $0.17-0.23 \mathrm{~mm}$, and spicule was $2.12-3.36 \mathrm{~mm}$. The body length and width of the female worm were $85-130 \mathrm{~mm}$ and $1.28-1.71 \mathrm{~mm}$, respectively. The head diameter was $0.29-0.38 \mathrm{~mm}$. Dorsal and ventrolateral lips almost have the same size that was $0.13-0.16 \times 0.15-0.19 \mathrm{~mm}$. The interlabial length was $0.08-0.10 \mathrm{~mm}$, esophagus was $3.04-4.67 \mathrm{~mm}$, and tail was $0.22-0.31 \mathrm{~mm}$. The distance of the vulva from the anterior edge was $56-88 \mathrm{~mm}$ with an average of $67.35 \mathrm{~mm}$. The eggs have conspicuously pitted with length $0.08-0.09 \mathrm{~mm}$ and width $0.07-0.08 \mathrm{~mm}$
\end{abstract}

Conclusion: Based on the characteristics of morphology and morphometry, the ascaroid worms found on $X$. piscator snake from Sidoarjo, Indonesia, were $O$. piscatori.

Keywords: carmine, Ophidascaris piscatori, scanning electron microscopy, Sidoarjo Indonesia, Xenochrophis piscator snake.

\section{Introduction}

The Xenochrophis piscator is a non-venomous snake that is widely found in Indonesia and distributed on the islands of Sumatra, Java, and Kalimantan [1]. This snake is widely traded and used as traditional medicine (meat, blood, and bile) or accessories (leather) or as a pet [2]. X. piscator is also called checkered keelback snake or Asiatic water snake because the habitat of this snake is freshwater lake or river [3].

The most common health problem faced by $X$. piscator snake is an endoparasite infection. According to Rajesh et al. [4], reptiles may contain various worms

Copyright: Suwanti, et al. Open Access. This article is distributed under the terms of the Creative Commons Attribution 4.0 International License (http://creativecommons.org/licenses/ by/4.0/), which permits unrestricted use, distribution, and reproduction in any medium, provided you give appropriate credit to the original author(s) and the source, provide a link to the Creative Commons license, and indicate if changes were made. The Creative Commons Public Domain Dedication waiver (http:// creativecommons.org/publicdomain/zero/1.0/) applies to the data made available in this article, unless otherwise stated. which, according to Klingenberg [5], may cause gastrointestinal obstruction, nutritional deficiencies, and tissue necrosis and are susceptible to secondary infection by bacteria. This will cause the snake to be more susceptible to diseases, affect the body's appearance (esthetics), and may even cause death.

Various types of worms are reported to infect snakes. One of them that can infect the snake is ascaroid nematode including Ophidascaris spp. Ophidascaris spp. is commonly found as parasite in snakes worldwide [6], and several researchers have found Ophidascaris spp. in various snacks [6-13].

In Tulangan district, Sidoarjo, East Java, Indonesia, there is snake slaughterhouse. The snake products were exported as snake meat and leather. $X$. piscator was one type of snake that is routinely slaughtered, and our previous study [14] found 426 nematode worms from snake's stomach. This study was conducted to describe the morphology and morphometry of nematode found in the stomach of 
$X$. piscator macroscopic and microscopically using light and scanning electron microscopy (SEM).

\section{Materials and Methods}

\section{Ethical approval}

This study was reviewed and approved by the Animal Care and Use Committee of Faculty of Veterinary Medicine, Universitas Airlangga, number 678-KE.

\section{Research materials}

The research material for routine microscopic examination consisted of aquadest, phosphate buffer saline with $\mathrm{pH} 7.2,70 \%, 85 \%$, and $95 \%$ alcohol, $10 \%$ formalin, 5\% glycerine alcohol, Hung's I, Hung's II, and carmine solution, acidic alcohol, alkaline alcohol, and $\mathrm{HCl}$ solution.

For SEM examination, the research materials were $\mathrm{NaCl}$ solution, buffer phosphate with $\mathrm{pH} 7.4$ for cleaning/washing samples, $2 \%$ glutaraldehyde and $1 \%$ osmic acid solution for worm fixation, $30 \%$, $50 \%, 70 \%, 80 \%, 90 \%$ and absolute alcohols for worm dehydration, and absolute amyl acetate to preserve the worms before dried as well as pure gold or carbon to coat the worms.

\section{Research tools}

The tools used in this study are surgical instruments (such as anatomical tweezers, scalpel blades, and scissors), Petri dishes, plastic trays, microscopic slides, cover glass (coverslip), scissors, beaker glass, Erlenmeyer, staining jar, disposable syringe, tissue or paper towels, tube rack, plastic pipette, Glass Graduated Cylinder, light microscope, and JSM-5000 SEM.

\section{The sample}

The samples were 40 nematode worms (20 male and 20 female) that have been collected from the stomach of $60 \mathrm{X}$. piscator snakes that slaughtered in district Tulangan, Sidoarjo, East Java, from December 2016 to April 2017. The worms taken from the stomach of the snake were washed and immersed in a $\mathrm{NaCl}$ $0.9 \%$ solution and were stored and identified at the Department of Veterinary Parasitology, Faculty of Veterinary Medicine, Universitas Airlangga.

\section{Macroscopic identification}

Macroscopic identification was done by observing the color, anterior and posterior shapes, and body length of the worm.

\section{Microscopic identification}

Twenty (10 male and 10 female) worms were stained with carmine. Worms were immersed in a 5\% glyceride alcoholic solution for $24 \mathrm{~h}$ and then in $70 \%$ alcohol for $5 \mathrm{~min}$. The worms were transferred into an alcoholic carmine solution (1:2) for approximately $8 \mathrm{~h}$, and then, it was soaked into acidic alcohol for $10 \mathrm{~min}$ and alkaline alcohol for $20 \mathrm{~min}$. Respectively, the worms were dehydrated into $70 \%, 85 \%$, and $95 \%$ alcohol for $5 \mathrm{~min}$. Mounting was done with Hung's I solution for $20 \mathrm{~min}$ and placed on clean object glass. Hung's II solution was dripped sufficiently over the worm and covered with a cover glass. Slides were dried in the incubator at $37^{\circ} \mathrm{C}[15]$. Worms were observed using a light microscope based on the method of Soota and Chaturvedi [7] with 40 and 100×.

To get worm eggs, some female worms were incubated in buffer saline at $37^{\circ} \mathrm{C}$ for $24 \mathrm{~h}$. The day after, buffer saline was centrifuged at $1500 \mathrm{rpm}$ for $5 \mathrm{~min}$, and sediment was dropped in slide glass and was observed under a light microscope with $100 \times$. Twenty nematode worms were sent to the Indonesian Science Institute for ultrastructure observation by SEM.

\section{Results}

The nematode worms were found inside the snake stomach (Figure-1a). Macroscopically, the worm appears brownish on the anterior and white on the posterior. The posterior body part is wider than the anterior portion, especially in the female worm (Figure-1b and c). The female worms have a larger size and length than the male (Figure-1c).

The shape of the mouth is similar to the other ascaridoid, which has three lips with almost the same size (Figures-2a, 3a, 3b and 3d). The dorsal portion of the lips has two double papillae, whereas in the lateroventral lips, each has one double papilla, one single papilla, and an amphid (Figures-3b and 3c). There was interlabial, which is one of the characteristics of ascaroid worm. Interlabia develops well with a deep post-labial groove (Figure-3b), with an interlabial length of nearly half the size of the lip length (Figure-3d). Ventrolateral anterior has cervical alae (Figure-3a). The esophagus and the border between the esophagus and intestine are clearly visible (Figure-2b). The cuticles are appeared with transverse striation (Figure-2b-d). The posterior portion of the male worm is bent to ventral, and there are spicules

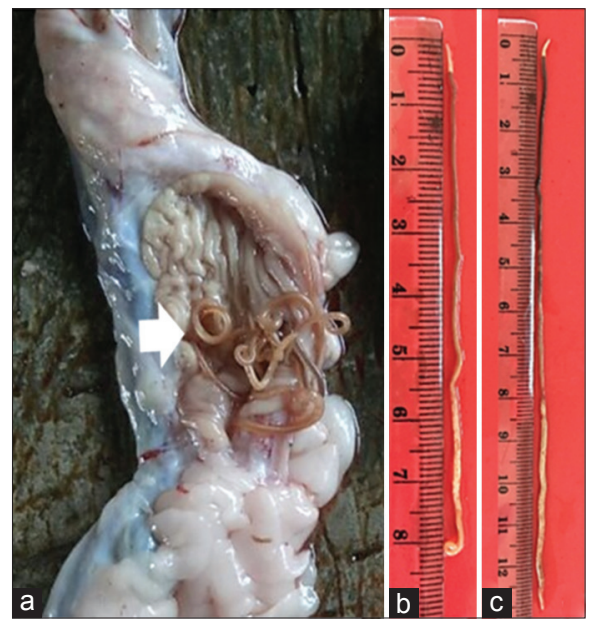

Figure-1: Fresh ascaroid nematode worms. (a) Worms in the stomach of Xenochrophis piscatori (white arrow). (b) Male worm. (c) Female worm. 
that are sometimes protruded (Figures- $1 \mathrm{~b}$ and $2 \mathrm{~d}$ ), and in ventrolateral, there is a row of papillae (Figure-3f). In the posterior portion of the female worm, the posterior edges are rounded, while in the male worm, the posterior end is tapered (Figure-1c and 2d). The female vulva of the female worm lies approximately two-third from the anterior body (Figure-2e). The anus is located near the posterior end (Figure-3e).

The body length and width of the male worm were $70-105 \mathrm{~mm}(87.2 \mathrm{~mm})$ and 0.92-1.32 $(1.13 \mathrm{~mm})$, respectively. The head diameter was $0.22-0.28 \mathrm{~mm}$ $(0.26 \mathrm{~mm})$. Dorsal and ventrolateral lips almost have the same size that was $0.10-0.12 \times 0.11-0.13 \mathrm{~mm}$ $(0.10 \times 0.12 \mathrm{~mm})$. The length of interlabia was 0.06 $0.08 \mathrm{~mm}(0.07 \mathrm{~mm})$, esophagus was $3.21-4 \mathrm{~mm}$ $(3.58 \mathrm{~mm})$, tail was $0.17-0.23 \mathrm{~mm}(0.19 \mathrm{~mm})$, and spicule was $2.12-3.36 \mathrm{~mm}(2.88 \mathrm{~mm})$ with rounded edges.

The body length and width of the female worm were $85-130 \mathrm{~mm}(103 \mathrm{~mm})$ and $1.28-1.71 \mathrm{~mm}$ $(1.46 \mathrm{~mm})$. The head diameter was $0.29-0.38 \mathrm{~mm}$ $(0.33 \mathrm{~mm})$. Dorsal and ventrolateral lips almost have the same size that was $0.13-0.16 \times 0.15-0.19 \mathrm{~mm}$ $(0.14 \times 0.18 \mathrm{~mm})$. The interlabial length was 0.08 $0.10 \mathrm{~mm}(0.09 \mathrm{~mm})$, esophagus was $3.04-4.67 \mathrm{~mm}$ $(3.8 \mathrm{~mm})$, and tail was $0.22-0.31 \mathrm{~mm}(0.26 \mathrm{~mm})$. The distance of the vulva from the anterior edge was $56-88 \mathrm{~mm}$ with an average of $67.35 \mathrm{~mm}$. The egg length and width were 0.08-0.09 $\mathrm{mm}$ and 0.07$0.08 \mathrm{~mm}$. The egg was rounded with a shell that has conspicuous pits (Figure-2f).

\section{Discussion}

Nematode worm in this study had three lips with almost the same size and it had papillae, so it was included in ascaridoid. The mouth of ascaridoids has three lips, the dorsal bearing two large outer papillae and the each lateroventral with one papilla [6]. Ascaridoid nematodes are very common in snakes, and Ophidascaris is an Ascarididae family of nematode often found in reptiles [12].

Some researchers had identified Ophidascaris species. Differential features of lip shape, esophageal length and spicules, tail, the number and arrangement of paracloacal and postcloacal papillae, and egg morphology are commonly used to recognize different species of Ophidascaris [9]. Ophidascaris durissus had found from Crepitus durissus snake in Brazil [6], Ophidascaris filaria was found in an Indian python in Sistan [10], and Ophidascaris excavata was found in the pit viper Gloydius brevicaudus in the Republic of Korea [11].

Based on host and morphologic and morphometrics of worm, compared with the method of Soota and Chaturvedi [7], the ascaridoid nematode found in this study was $O$. piscatori, although there were some difference sizes, especially on lip width which is more narrow as found in this study (Table-1) [7].
$O$. piscatori has the following characteristics: Predilection in snake stomach, roundworm, whitish color with brownish in anterior portion, the mouth with three lips similar in size, interlabial, deep post-labial grooves, present cervical alae, and a clear border between the esophagus and intestine. Vulva of the female worm lies approximately two-third from the anterior body and posterior part of the male worm is bent ventral, and there were spicules that were sometimes protruded.

In Indonesia, Ophidascaris spp. had also found in Python snakes form Bali [13] and Depok and

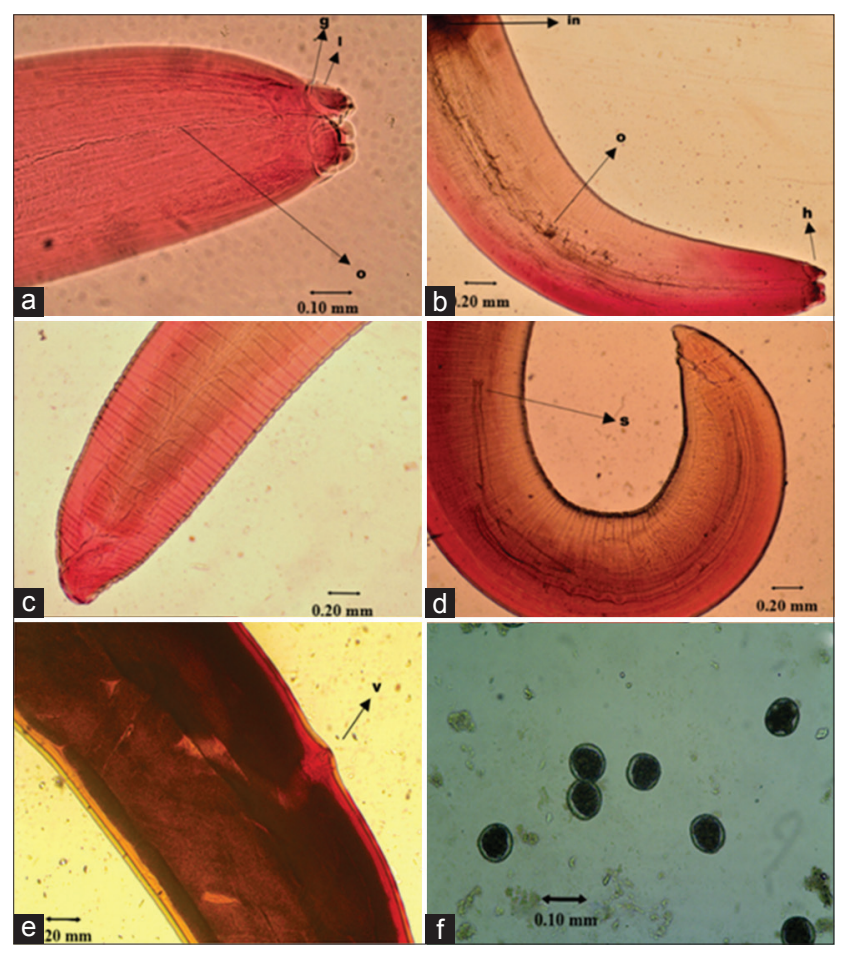

Figure-2: Ophidascaris piscatori with carmine stain. ( $a$ and $b$ ) anterior $(\times 100$ and $\times 40)$. (c and e) Posterior of female worm $(\times 40)$. (d) Posterior of male worm $(\times 40)$. (f) Worm eggs $(\times 100)$. g: Post-labial groove; I: Lips; o: Esophagus; in: Intestine; s: Spicule, v: Vulva.

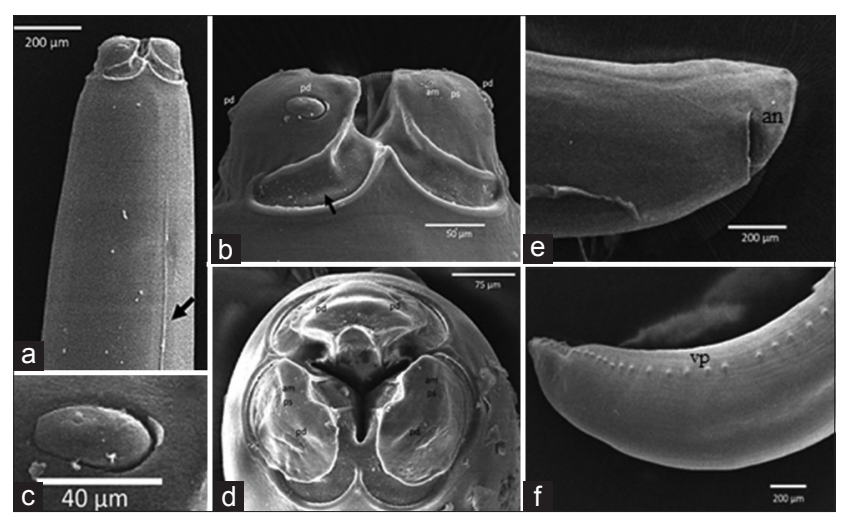

Figure-3: Ophidascaris piscatori with scanning electron microscopy. (a-d) Anterior; (e and f) posterior; (a) ventrolateral with cervical alae (black arrow). (b) The head with lips, interlabial, and deep post-labial grooves. (c) Detail of double papillae. (d) Apical of the head; (e) Posterior of female worm; (f) posterior of male worm. am: Amphid; an: Anus; pd: Double papillae; ps: Single papillae, vp: Ventrolateral papillae. 


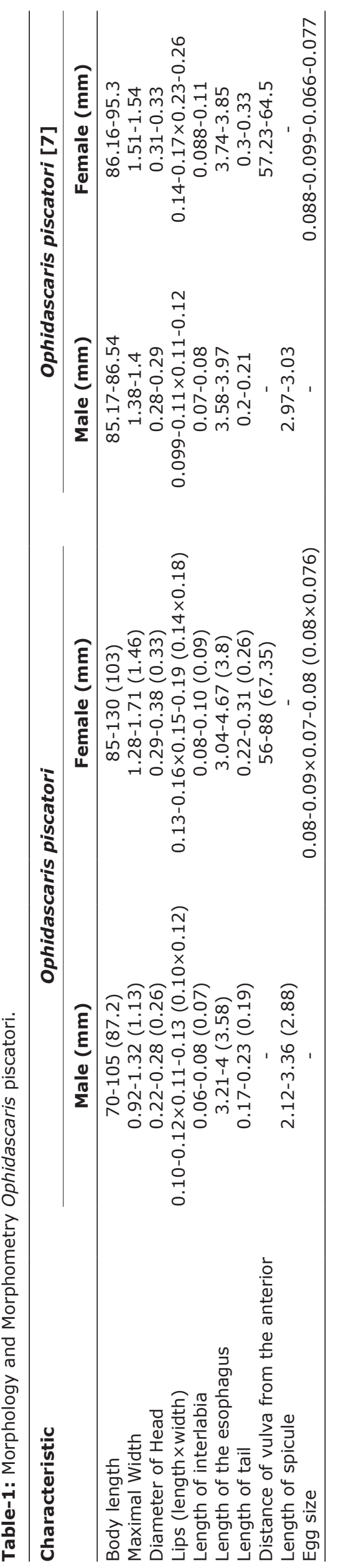

Bogor [16]. They just found eggs of worm, and based on the examination, the size and shape of eggs were different from this study. Ophidascaris spp. eggs found in Bali are an oval-shaped and thick shell with length and width average 0.09 and $0.04 \mathrm{~mm}$. In this study, the egg has conspicuously pitted with length and width average 0.08 and $0.076 \mathrm{~mm}$.

\section{Conclusion}

Based on the characteristics of morphology and morphometry, the ascaroid worms found on X. piscator snake from Sidoarjo, Indonesia, were O. piscatori. Body length of the male worm was $70-105 \mathrm{~mm}$, and the female was $85-130 \mathrm{~mm}$. The eggs have conspicuously pitted with length $0.08-0.09 \mathrm{~mm}$ and width 0.07-0.08 mm.

\section{Authors' Contributions}

LTS, ISA, SK, and EDP designed the concept for this research and scientific paper. LTS and ISA conducted the research, for example, collecting samples and did the laboratory work. All authors participated in draft and revision of the manuscript and approved the final manuscript.

\section{Acknowledgments}

The authors gratefully acknowledge the Faculty of Veterinary Medicine, for financial support with research grant through the Annual Plan of Activities and Budget 2017.

\section{Competing Interests} interests.

The authors declare that they have no competing

\section{References}

1. Hoser, R.T. (2012) Divisions of the Asian colubrid snake genera Xenochrophis, Dendrelaphis and Boiga (Serpentes: Colubridae). Aust. J. Herpetol., 12: 65-76.

2. Tajalli, A., Wiradityo, C. and Wijaya, I.M. (2012) Reptile National Park Bukit Baka Bukit Raya and utilization traditionally by Dayak society, West Kalimantan. Student Creativity Program. Department of Forest Resources Conservation and Ecotourism, IPB, Bogor. p1-10.

3. Gowda, A.K.J., Rani, B.K., Nandeesha, C. and Naravi, Y. (2016) Ascaridia galli infection in a checkered keelback (Xenochrophis piscator) snake. J. Parasitol. Dis., 41(1): 86-89.

4. Rajesh, N.V., Rajesh, K.D., Jayathangaraj, M.G., Raman, M. and Sridhar, R. (2015) Parasitic fauna of captive snakes in Tamilnadu, India. Asian Pac. J. Trop Dis., 5(7): 547-551.

5. Klingenberg, R.J. (2007) Understanding Reptile Parasites. $2^{\text {nd }}$ ed. Advanced Vivarium Systems Inc. Singapore, USA. p24-32.

6. Panizzutti, M.H.M., Santos, L.C.D., Vicente, J.J., MunizPereira, L.C. and Pinto, R.M. (2003) Ophidascaris durissus sp. nov. (Nematoda Ascarididae) parasitizing Crotalus durissus linnaeus (Ophidia, Viperidae) in Brazil. Rev. Bras. Zool., 20(1): 9-11.

7. Soota, T.D. and Chaturvedi, Y. (1970) On five new species of nematodes from vertebrates. Proceedings: Plant Sci., 71(3): 100-108.

8. Biswas, D., Das, S. and Alim, M.A. (2014) The first record of Ophidascaris (Nematode: Ascarididae) in the Asian rock python (Python molurus molurus) in Bangladesh. Scholarly 
J. Agric. Sci., 4(1): 24-26.

9. Li, L., Guo, Y.N., Li, J. and Zhang, L.P. (2014) Ophidascaris wangi sp. n. and O. najae (Gedoelst, 1916) (Ascaridida: Ascarididae) from snakes in China. Folia. Parasitol., 6: 571-580.

10. Ganjali, M., Keighobadi, M. and Khedri, J. (2015) First report of Ophidascaris filaria (Nematode: Ascarididae) from the Indian Python in Sistan, Iran. Comp. Clin. Pathol., 24(5): 1285-1288.

11. Choe, S., Lim, J., Kim, H., Kim, Y., Kim, H., Lee, D., Park, H., Jeon, H.K. and Eom, K.S. (2016) Three nematode species recovered from terrestrial snakes in Republic of Korea. Korean J. Parasitol., 54(2): 205.

12. Sundar, S.B., Kavitha, K.T., Gomathinayagam, S., Sangaran, A., Latha, B.R. and Harikrishnan, T.J. (2016) A report on the incidence of Ophidascaris sp. in a reticulated python. Int. J. Sci. Environ. Tech., 5(5): 3328-3331.
13. Telnoni, F.R., Oka, I. and Widyastuti, S.K. (2016) Prevalence of nematode infection at Python reticulatus snake reared by snakes lovers in Denpasar. Indonesia Med. Vet., 5(2): 104-112.

14. Audini, IS. (2017) Helminthiasis in Xenochopis piscator snake in Tulangan District, Sidoarjo, East Java. Thesis. Universitas Airlangga Surabaya.

15. Agustin, A.L.D, Koesdarto. S., Lukiswanto, B.S., Suwanti, L.T., Arifin, A. and Putranto, E.D. (2017) Morphological Identification Nematodes Tanqua tiara found on gastric Varanus salvator at East Java. The Veterinary Medicine International Conference 2017, KnE Life Sciences. p668-676.

16. Rahmayani, I. (2014) Worm infection of Sanca snake digestive system (Python reticulatus Schneider 1810) as exotic pets. Faculty of Veterinary Medicine Institut Pertanian Bogor, Indonesia. p10.

$* * * * * * * *$ 